\title{
Effectiveness of Text Message Reminders on Adherence to Inhaled Therapy in Patients With Asthma: Prospective Multicenter Randomized Clinical Trial
}

Carlos Almonacid ${ }^{1}, \mathrm{MD}, \mathrm{PhD}$; Carlos Melero $^{2}, \mathrm{MD}, \mathrm{PhD}$; Antolín López Viña ${ }^{3}$, MD, PhD; Carolina Cisneros ${ }^{4}, \mathrm{MD}$, PhD; Luis Pérez de Llano ${ }^{5}$, MD, PhD; Vicente Plaza ${ }^{6}, \mathrm{MD}$, PhD; Juan Luis García-Rivero ${ }^{7}, \mathrm{MD}, \mathrm{PhD}$; Auxiliadora Romero Falcón ${ }^{8}$, MD, PhD; Jacinto Ramos ${ }^{9}, \mathrm{MD}$, PhD; Teresa Bazús González ${ }^{10}$, MD, PhD; María Andrés Prado ${ }^{11}$, $\mathrm{MD}, \mathrm{PhD}$; Alfonso Muriel ${ }^{12}$, MD, PhD

\footnotetext{
${ }^{1}$ Department of Respiratory Medicine, Instituto Ramón y Cajal de Investigación Sanitaria, University of Alcala de Henares, Madrid, Spain

${ }^{2}$ Department of Respiratory Medicine, Hospital Universitario 12 de Octubre, Institute for Health Research (i+12), Complutense University of Madrid, Madrid, Spain

${ }^{3}$ Department of Respiratory Medicine, Hospital Universitario Puerta de Hierro, Autonoma University of Madrid, Majadahonda, Spain

${ }^{4}$ Department of Respiratory Medicine, Hospital Universitario La Princesa, Autónoma University of Madrid, Madrid, Spain

${ }^{5}$ Department of Respiratory Medicine, Hospital Universitario Lucus Augusti, University of Lugo, Lugo, Spain

${ }^{6}$ Department of Respiratory Medicine, Hospital de la Santa Creu i Sant Pau, Institut d'Investigació Biomédica Sant Pau, Autònoma University of Barcelona, Barcelona, Spain

${ }^{7}$ Department of Respiratory Medicine, Laredo Hospital, Laredo, Spain

${ }^{8}$ Department of Respiratory Medicine, Hospital Universitario Reina Sofia, University of Cordoba, Córdoba, Spain

${ }^{9}$ Department of Respiratory Medicine, Hospital Universitario de Salamanca, University of Salamanca, Salamanca, Spain

${ }^{10}$ Department of Respiratory Medicine, Hospital Universitario Central de Asturias, University of Oviedo, Oviedo, Spain

${ }^{11}$ Department of Health Information Management, Fundación Jimenez Diaz, Madrid, Spain

${ }^{12}$ Unit of Clinical Biostatistics, Instituto Ramón y Cajal de Investigación Sanitaria, Consorcio Centro de Investigación Biomédica en Red de Epidemiología y Salud Pública, University of Alcala de Henares, Madrid, Spain
}

\section{Corresponding Author:}

Carlos Almonacid, MD, PhD

Department of Respiratory Medicine

Instituto Ramón y Cajal de Investigación Sanitaria

University of Alcala de Henares

Ctra. De Colmenar Viejo, km. 9,100

Madrid,

Spain

Phone: 34655534475

Email: caralmsan@gmail.com

\section{Abstract}

Background: Poor adherence to inhaled medication in asthma patients is of great concern. It is one of the main reasons for inadequate asthma control.

Objective: The goal of the research was to determine if motivational messages using short message service (SMS, or text) improved adherence to inhaled medication in patients with asthma.

Methods: A prospective multicenter randomized parallel-group clinical trial was conducted in 10 asthma clinics in Spain. Adherence was assessed with electronic monitors (Smartinhaler, Adherium Ltd) connected to inhalers. Patients in the SMS group received psychologist-developed motivational messages every 3 days for 6 months.

Results: There were 53 patients in the SMS group and 88 patients in the control group. After 6 months, mean electronic adherence was 70\% (SD 17\%) in the intervention group and 69\% (SD 17\%) in the control group ( $P=.82$ ). Significant differences between the study groups in morning and evening adherence to inhaled therapy, asthma control, exhaled nitric oxide levels, or improvement of lung functions were not observed. 
Conclusions: Motivational messages were not useful to improve adherence to inhaled asthma medication compared with usual care.

(JMIR Form Res 2021;5(2):e12218) doi: 10.2196/12218

\section{KEYWORDS}

asthma; adherence; SMS; control; cell phone; inhaler; Smartinhaler

\section{Introduction}

Epidemiological studies show a high prevalence of poor asthma control [1-3]. Poor adherence is one of the most frequent causes of this problem [2-18]. The measurement of adherence to inhalers is a complicated task. Different methods have been used in daily practice, including clinical judgment, response to treatment, generally validated self-report questionnaires [19], or specifically designed instruments such as the Test of Adherence to Inhalers [20,21]. All these methods tend to overestimate treatment adherence [22,23]. Exhaled nitric oxide (FeNO) measurement has been proposed as an objective technique to measure treatment compliance [24]. In the last 30 years, electronic monitoring devices have been developed with this proposal [25-28]. These devices can record the time and number of doses taken and remind the patient to take medication.

Adherence to inhaled therapy depends on multiple factors. Asthma education programs plus information and communication technologies could be more useful to improve adherence than using them separately. All cell phones can send or receive short message service (SMS, or text) messages, which are a convenient, widely used mode of communication [29-32]. It has been shown that text messages improve appointment adherence [10], but very little research has focused on the effect of messages to reinforce adherence using SMS.

Several studies reviewed the effect of reminders on asthma control and adherence to treatment [33-40]. Only a few studies have used electronic devices to assess adherence to inhalers. In these studies, reminders were also sent through the same electronic device (SmartTrack or Smartinhaler [both Adherium Ltd]) that measured adherence to treatment, not through SMS $[39,40]$. Other studies used self-report questionnaires to measure inhaler adherence, but this leads to decreases the quality of the results. To date, a benefit in adherence to treatment from motivational text messages sent to a cell phone has not been reported.

The objective of this study is to measure the effect of motivational messages designed by a psychologist on treatment adherence compared with usual care in patients with moderate to severe asthma.

\section{Methods}

\section{Trial Design}

We conducted a parallel-group randomized controlled trial in patients with moderate or severe asthma at 10 university hospitals in Spain. Patients were recruited from 2013 to 2014. Patients were randomized to an SMS group or a control group; follow-up was for 6 months.

\section{Participants}

The eligibility criteria for participants were (1) aged 18 to 85 years, (2) asthma diagnosed according to the Global Initiative for Asthma (GINA) criteria [41], (3) all patients treated with maintenance therapy according GINA guidelines, (4) currently own cell phone, (5) not currently being treated with systemic corticosteroids or biologic drugs, (6) not currently participating in another research study.

Exclusion criteria were (1) inability to use inhaler devices [30]; (2) other associated chronic respiratory disease (eg, chronic obstructive pulmonary disease); (3) previous participation in a study using SMS-related asthma reminders (4) asthma exacerbation within 3 months of inclusion in the study (defined by oral corticosteroid use, emergency department visit, or hospitalization); (5) previous treatment with budesonide/formoterol as maintenance and reliever therapy; (6) other uncontrolled severe medical conditions.

\section{Interventions}

The SMS group received psychologist-developed motivational messages every 3 days for 6 months in addition to usual care recommendations according to GINA guidelines [41]. SMS messages were not reminders to take a dose of medication. The control group was treated with general care recommendations alone according to GINA guidelines [41]. Four study visits were required ( 1 for enrollment and 3 for follow-up) in both groups. Outcome data were collected at the clinic by study staff in V0, V1 (1 month later), V3 (3 months later), and V6 (6 months later-end of study).

\section{Medications and Inhaler Monitoring}

All patients received a SmartTrack device (Smartinhaler [Adherium Ltd]; Figure 1) that clipped on their ICS/LABA inhaler. SmartTrack is an electronic device that allows measuring adherence to the inhalers. Each puff is recorded in the device memory. SmartTrack records the date and time the inhaler was used and the number of puffs taken. SmartTrack features include reminders, onscreen questions about asthma control, and medication feedback viewing online, but these have been deactivated. After the device was activated during the enrollment (visit 0), it recorded the date and time of all maneuvers to measure adherence to treatment. The data were uploaded to a secure cloud server with local backup to the investigator's computer. 
Figure 1. SmartTrack devices connected to pressurized metered-dose inhaler (left) and Turbuhaler inhalation device (right).

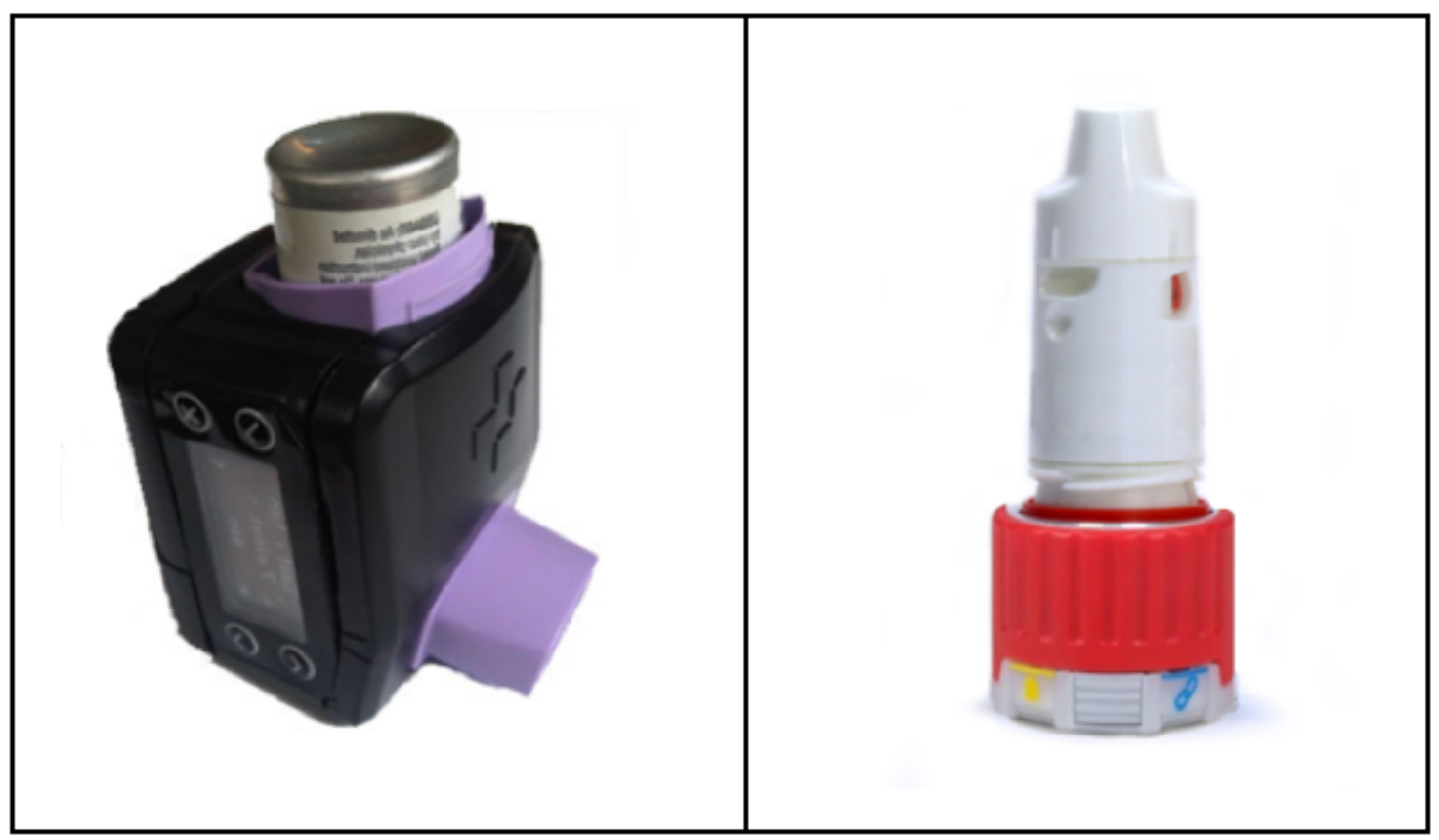

Patients were treated with an ICS/LABA inhaler for maintenance therapy (fluticasone propionate/salmeterol Accuhaler/Diskus inhaler, budesonide/formoterol Turbuhaler inhaler, or beclomethasone/formoterol metered-dose inhaler). They also used albuterol pressurized metered-dose inhaler as rescue medication. Device reliability and precision have been reported according to other publications [38].

\section{SmartTrack Training and Monitoring}

Electronic monitoring via the Smartinhaler was used to assess adherence to inhaled asthma therapy. All patients received brief instructions on the use of the SmartTrack. Patients with adherence higher than $80 \%$ were considered regular adherents. Electronic monitors were attached to participant controller medications in the SMS and control groups.

\section{Text Messages}

Patients assigned to the intervention group only received SMS communications about the importance of asthma medication every 3 days for 6 months; messages were not reminders to take a dose of medication. The messages, written by a psychologist in collaboration with pulmonologists, were randomly switched every 3 days and include the following:

- Remember that performing the treatment of inhaled medication keeps your asthma controlled.

- Inhaled medication helps to maintain asthma control.

- Remember to take inhaled medication; it keeps you well.

- Have you taken your inhaled medication?

- Do you take your inhaled medication in the morning and the evening?

- Maybe now is the time to take your inhaled medication.

- Remember to take inhaled medication as prescribed by your doctor.

\section{Asthma Education}

All patients were provided an asthma action plan on the first day written in accordance with the GINA guidelines. Inhaler technique was reviewed, and any problems were corrected. At each visit, inhaler technique and the asthma action plan were reviewed.

\section{Asthma Control}

Asthma control was measured using the Asthma Control Test (ACT) [42], and a score $\geq 20$ identified well-controlled asthma patients.

\section{Pulmonary Function}

Spirometry with bronchodilator test was performed according to the European Respiratory Society/American Thoracic Society (ERS/ATS) guidelines [43]. Values for the Mediterranean population were used [44]. Forced expiratory volume in 1 second (FEV1) pre and postbronchodilator were measured.

\section{Fractional Exhaled Nitric Oxide}

An FeNO level was measured before spirometry using the equipment available in each center. The test was performed following the ERS/ATS recommendations [45].

\section{Outcomes}

Demographic data, ACT, lung function (spirometry), FeNO levels, and exacerbation history in the previous year were collected at the enrollment visit (V0). ACT, lung function, FeNO levels, and exacerbation history were also collected at V1, V3, and V6.

The primary outcome was adherence to inhaled medication. SmartTrack devices were used to quantify adherence to control medication. The secondary outcomes were asthma control measured by the ACT, spirometry parameters (FEV1, forced 
vital capacity, and FEV1/forced vital capacity ratio), FeNO levels, number of asthma exacerbations, visits to the emergency department, and hospital admissions due to asthma.

\section{Sample Size}

The sample size was calculated according to an adherence rate to inhaled asthma therapy between $30 \%$ and $70 \%$ [9]. On the assumption of the maximal uncertainty of $50 \%$ and considering a clinically relevant difference of $25 \%$, with a type I error of .05 , a power of $80 \%$, and a $20 \%$ loss, 73 patients per arm were needed (total 146 patients).

\section{Randomization, Blinding, and Allocation Concealment}

We generated the 2 comparison groups using simple randomization with an equal allocation ratio by referring to a table of random numbers. A mathematician, also in charge of randomization of the SMS sending, generated the sequences of random allocation, who enrolled participants, and who assigned participants to interventions and SMS sending.

Blinding of patients was not possible. To avoid bias and with ethics approval, physicians were not notified about the SmartTrack recording function or SMS intervention until the study ended.

\section{Statistical Methods}

Categorical variables were expressed as frequencies and percentages and continuous variables as means and standard deviations. The chi-square or Fisher exact test were used for the analysis of categorical variables, and the Student $t$ test or Mann-Whitney $U$ test were used for the comparison of quantitative variables according to the standard or nonnormal distribution of variables. Tests were 2-tailed. Statistical significance was set at $P<.05$. Statistical analyses were performed using the SPSS Statistics version 20.0 (IBM Corp).

\section{Ethics Approval and Trial Registration}

The clinical research ethics committees of the participating centers approved the study. All participants provided written informed consent. The study was classified by the Spanish Agency of Medicines and Medical Devices as a noninterventional imposed postauthorization safety study, and for this reason we were not required to register the clinical trial.

\section{Results}

\section{Patient Participants}

Of patients recruited, 63.8\% (97/152) were women. At the first data collection time point, the mean age was 48.9 (SD 16.7) years, and the mean duration of asthma was 16.5 (SD 13) years. A total of $6.6 \%(10 / 152)$ of patients were current smokers. Most patients were well controlled at enrollment, with a mean ACT score of 20.2 (SD 4.5) points. The mean FEV1 before the bronchodilation test was 79\% (SD 17.9\%) predicted, the mean FEV1 after bronchodilation test was $82.5 \%$ (SD 16.2\%) predicted, and the mean FeNO level was 37.9 (SD 35.9) ppb. A total of $13.2 \%(20 / 152)$ of patients reported one or more exacerbations during the last 12 months, $15.8 \%$ (24/152) reported an episode of asthma-related urgent health care utilization and prednisone use in the previous year, and 5.9\% (9/152) required admission to hospital.

A failure with the randomization program unbalanced the number of patients in both arms. During the study period, 57 patients were assigned to the intervention group, and 95 to the control group. At follow-up, 11 patients were excluded because of the total failure of the electronic monitoring device. The final analysis included 53 patients in the intervention group and 88 in the control group. The flowchart of the study population is shown in Figure 2. Demographic and baseline characteristics were similar between groups, apart from a lower proportion of men and university education in the SMS group (Table 1). 
Figure 2. Flow diagram of the progress through the phases of a parallel randomized trial of two groups.

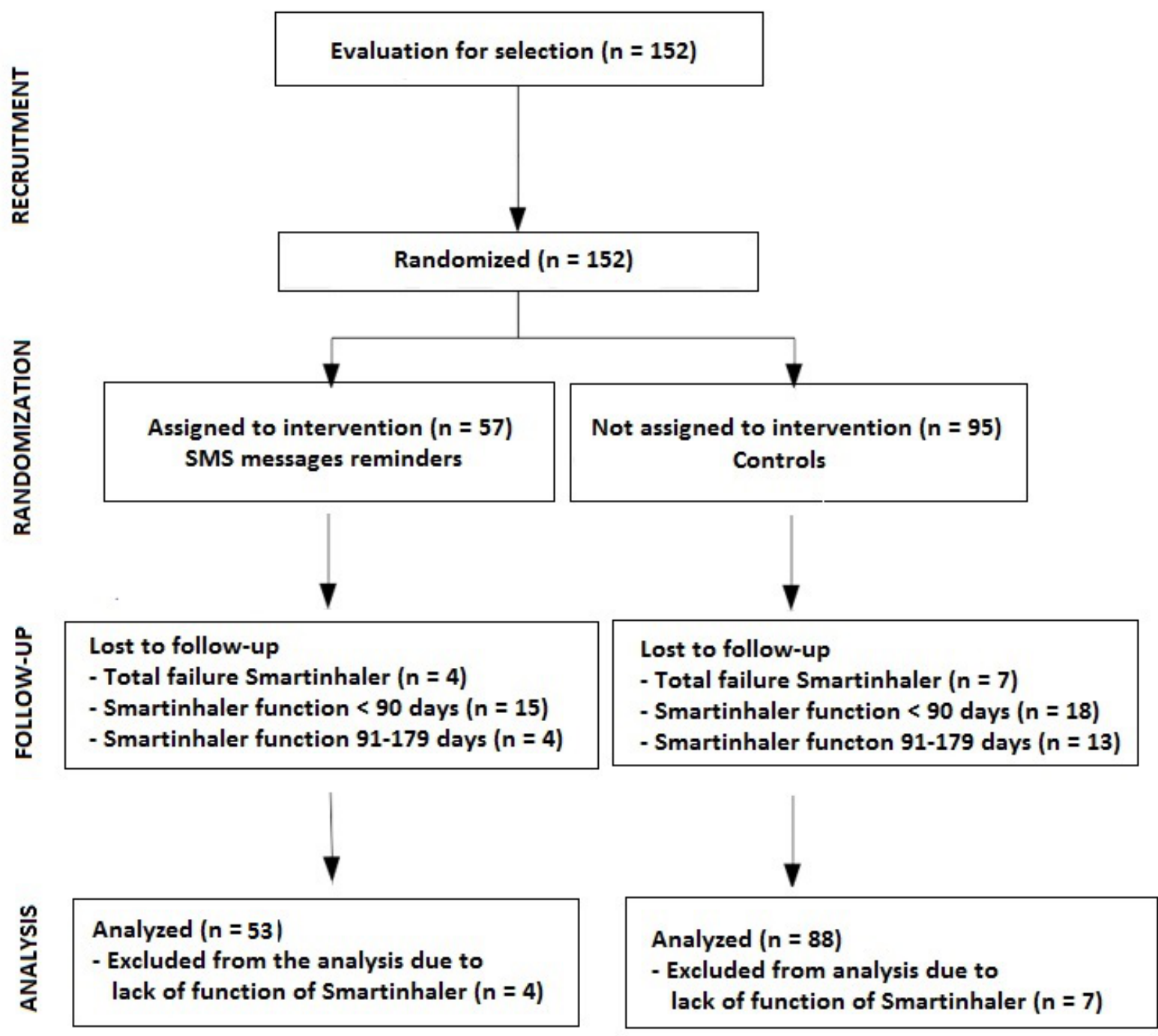


Table 1. Clinical characteristics of patients at baseline.

\begin{tabular}{|c|c|c|c|}
\hline Variable & $\mathrm{SMS}^{\mathrm{a}}$ group $(\mathrm{n}=57)$ & Control group $(\mathrm{n}=95)$ & $P$ value \\
\hline Gender, male, n (\%) & $15(26)$ & $40(42)$ & .05 \\
\hline Age in years, mean (SD) & $50.4(16.4)$ & $48(16.9)$ & .40 \\
\hline \multicolumn{4}{|l|}{ Education level, n (\%) } \\
\hline Primary/secondary studies & $47(82)$ & $61(64)$ & .40 \\
\hline University degree & $7(12)$ & $20(21)$ & .40 \\
\hline \multicolumn{4}{|l|}{ Working status, n (\%) } \\
\hline Unemployed & $6(11)$ & $10(11)$ & .79 \\
\hline Employed & $34(60)$ & $54(57)$ & .79 \\
\hline Housewife & $4(7)$ & $11(12)$ & .79 \\
\hline Retired & $13(23)$ & $18(19)$ & .79 \\
\hline \multicolumn{4}{|l|}{ Smoking history, n (\%) } \\
\hline Current smoker & $4(7)$ & $6(6)$ & .75 \\
\hline Ex-smoker & $17(30)$ & $34(36)$ & .75 \\
\hline Never smoker & $36(63)$ & $55(58)$ & .75 \\
\hline Self-management education program, n (\%) & $10(18)$ & $16(17)$ & .91 \\
\hline \multicolumn{4}{|l|}{ Asthma history, mean (SD) } \\
\hline Years from diagnosis & $16.6(11.6)$ & $16.5(14.3)$ & .98 \\
\hline Years from starting treatment & $13.3(10.3)$ & $13.2(12.1)$ & .10 \\
\hline Years from follow-up in outpatient clinics & $7.2(7)$ & $6.8(7.8)$ & .78 \\
\hline \multicolumn{4}{|l|}{ Inhaler type, n (\%) } \\
\hline Accuhaler/Diskus & $18(32)$ & $38(40)$ & .57 \\
\hline Turbuhaler & $26(46)$ & $37(39)$ & .57 \\
\hline $\mathrm{pMDI}^{\mathrm{b}}$ & $13(23)$ & $20(21)$ & .57 \\
\hline \multicolumn{4}{|l|}{ Inhalation technique, correct steps, n (\%) } \\
\hline Acceptable & $40(70)$ & $75(79)$ & .22 \\
\hline Unacceptable & $17(30)$ & $20(21)$ & .22 \\
\hline \multicolumn{4}{|l|}{ Asthma-related events in the previous 12 months, mean (SD) } \\
\hline Exacerbations & $0.6(1.2)$ & $0.4(0.8)$ & .21 \\
\hline Emergency department visits & $0.2(0.6)$ & $0.2(0.7)$ & .79 \\
\hline Hospital admission & $0.05(0.2)$ & $0.04(0.2)$ & .76 \\
\hline Asthma Control Test, mean (SD) & $20.3(4.2)$ & $20.0(4.8)$ & 69 \\
\hline $\mathrm{FeNO}^{\mathrm{c}}$ level, ppb, mean (SD) & $42.2(37.5)$ & $33.7(34.3)$ & .18 \\
\hline FEV $1{ }^{\mathrm{d}}$ before bronchodilation test, $\%$ predicted, mean (SD) & $79.0(17.5)$ & $79.5(18.4)$ & .92 \\
\hline FEV1 after bronchodilation test, $\%$ predicted, mean (SD) & $79.6(16.7)$ & $85.3(15.7)$ & .16 \\
\hline
\end{tabular}

${ }^{\mathrm{a}} \mathrm{SMS}$ : short message service.

bMDI: pressurized metered-dose inhaler.

${ }^{\mathrm{c}} \mathrm{FeNO}$ : exhaled nitric oxide.

${ }^{\mathrm{d}}$ FEV1: forced expiratory volume in 1 second. 


\section{Adherence to Treatment}

\section{Primary Outcome}

Adherence data were recorded throughout the study starting from enrollment, and $92.8 \%$ (141/152) of patients had analyzable SmartTrack data. No adherence data were available for $7.2 \%(11 / 152)$ of patients due to device failure; $21.7 \%$ (33/152) of SmartTracks monitored adherence for at least 90 days, $11.2 \%$ (17/152) operated fine for between 90 and 179 days, and $59.9 \%$ (91/152) worked precisely until the study ended.
The data transmission software that communicated with the Smartinhaler platform failed throughout the study in most of the participating centers since it did not work with the hospital proxy servers. Due to this failure, the backup files generated during each visit were used for the analysis. Differences between the study groups were not found in SmartTrack failures $(P=.51)$.

After 6 months, the mean electronic adherence was $70 \%$ (SD $17 \%$ ) in the intervention group and 69\% (SD 17\%) in the control group $(P=.82)$. Adherence to inhalers was higher in both groups in the morning (control group 79\% [SD 19\%] vs 60\% [SD 24\%] in the afternoon and SMS group 80\% [SD 23\%] vs 59\% [SD $29 \%$ ] in the afternoon; Table 2).

Table 2. Results at the end of the study.

\begin{tabular}{|c|c|c|c|}
\hline Variables & $\mathrm{SMS}^{\mathrm{a}}$ group $(\mathrm{n}=53)$ & Control group $(\mathrm{n}=88)$ & $P$ value \\
\hline Adherence $\%$, mean (SD) & $70(17)$ & $69(17)$ & .82 \\
\hline Morning adherence $\%$, mean (SD) & $80(23)$ & $78(19)$ & .44 \\
\hline Evening adherence $\%$, mean (SD) & $59(29)$ & $60(24)$ & .75 \\
\hline Asthma Control Test score, mean (SD) & $21.6(3.7)$ & $22.1(3.5)$ & .46 \\
\hline $\mathrm{FeNO}^{\mathrm{b}}$ level, $\mathrm{ppb}^{\mathrm{c}}$, mean (SD) & $36.5(35.5)$ & $28.3(22.0)$ & .14 \\
\hline FEV $1^{\mathrm{d}}$ before bronchodilation test, $\%$ predicted, mean (SD) & $77.3(16.2)$ & $80.9(18.0)$ & .42 \\
\hline FEV1 after bronchodilation test, $\%$ predicted, mean (SD) & $85.9(12.4)$ & $84.5(16.2)$ & .73 \\
\hline Exacerbation episodes, $\mathrm{n}(\%)$ & & & .22 \\
\hline 0 & $37(84)$ & $68(92)$ & - \\
\hline 1 & $7(16)$ & $5(7)$ & - \\
\hline$\geq 2$ & 0 & $1(1)$ & - \\
\hline Visits to emergency department, n (\%) & & & .43 \\
\hline 0 & $40(91)$ & $71(95)$ & - \\
\hline 1 & $4(10)$ & $4(5)$ & - \\
\hline$\geq 2$ & 0 & 0 & - \\
\hline Hospital admission for asthma, $\mathrm{n}(\%)$ & 0 & 0 & - \\
\hline
\end{tabular}

${ }^{a}$ SMS: short message service.

${ }^{\mathrm{b}} \mathrm{FeNO}$ : exhaled nitric oxide.

${ }^{\mathrm{c}}$ ppb: parts per billion.

${ }^{\mathrm{d}} \mathrm{FEV} 1$ : forced expiratory volume in 1 second.

\section{Secondary Outcomes}

At the end of the study (V6), no differences were found between the SMS and control group in ACT, FEV1, FeNO levels, exacerbations, emergency department visits, or hospital admissions (Table 2).

\section{Discussion}

\section{Principal Findings}

In this study, motivational SMS was not associated with an improvement in adherence to inhaled medication. We also found no significant differences in secondary variables, asthma control, lung function, exhaled nitric oxide levels, or exacerbations due to asthma.

Education strategies are useful to improve adherence to asthma therapy [10]. Few studies have examined the effect of SMS reminders on adherence to asthma treatment. Strandbygaard et al [46] conducted a 12-week study with 26 asthma patients randomized to the SMS group $(n=12)$ or control group $(n=14)$. The SMS group received this message daily: "Remember to take your asthma medication morning and evening. From the Respiratory Unit." A medicine dose-count for Diskus inhaler was used to assess adherence. The mean adherence rate increased in the SMS group and decreased in controls, with a difference in mean adherence rate between the 2 groups after 12 weeks of $17.8 \%$ (95\% CI $3.2 \%-32.3 \% ; P=.02$ ). Changes in adherence in the SMS group, however, were not associated with clinical or functional improvement. Few patients were included 
in this study, and adherence may have been overestimated due to the possibility to take actions before the medical visit.

In another study, Charles et al [47] used the audiovisual reminder function on the Smartinhaler metered-dose inhaler device. After 12 weeks, the absolute difference in the median percentage of medication taken between the intervention $(\mathrm{n}=55)$ and control $(\mathrm{n}=55)$ groups was $18 \%$ (95\% CI 10\%-26\%; $P<.001)$. But, again, no improvements in clinical or lung functions were observed.

In a 6-month cluster-randomized study, Foster et al [35] assessed the effect of inhaler reminders plus adherence feedback $(n=21)$ versus usual care or personalized discussion with the general practitioners $(n=22)$ in the primary care setting. Reminders were associated with improvements in adherence (73\% [SD 26\%] vs $46 \%$ [SD 28\%] of prescribed daily doses, $P<.001)$ as well as with an improvement in the ACT but without differences between the study groups.

In a recent systematic review of interventions aimed at improving adherence to inhaled corticosteroids for asthma, 11 studies assessing electronic trackers or reminders versus control were analyzed [10]. Electronic trackers or reminders led to better adherence of 19 percentage points (95\% CI 14.47-25.26; 6 studies; moderate-quality evidence), but a clear benefit on clinical outcomes was not found.

\section{Limitations}

In our study, a simple intervention based on motivational SMS sent every 3 days for 6 months was not adequate to improve adherence. Different reasons may account for this adverse finding. First, the messages sent were motivational; they were not reminders for taking medication. Second, the pattern of nonadherence behavior (eg, erratic, deliberate, unwitting) [21] was not evaluated nor were patients stratified according to a nonadherent model. Third, asthma was well controlled at baseline as shown by high ACT scores and lung function parameters; the magnitude of improvement depends to a large extent on the degree of control of the disease before the intervention.
An interesting finding of this study, in which all patients had twice-daily medication schedules, is that adherence rates were higher in the morning than in the evening. It is possible that in patients on single-dose inhaled medication regimens, SMS could have had a more significant impact on adherence.

Although the Smartinhaler is accurate in recording and retaining actuation data $[48,49]$, potential malfunction during real-life use by patients is possible. In our study, failure of communication technology occurred in all centers without differences between the study groups; in these cases, however, analyses were performed using backup files. Only 91\% (SD $59.9 \%$ ) of the Smartinhalers worked fine and collected information until the study ended.

In our study, patients were recruited in specialized asthma units established in different hospitals throughout Spain for the management of patients with severe and difficult-to-control asthma [50]. Therefore, it is possible that this particular circumstance may account for the adequate adherence at baseline and proper control of asthma before enrollment and at the end of the study.

\section{Conclusions}

In summary, in this prospective randomized clinical study, reinforcement of adherence to inhaled asthma medication using motivational SMS via cell phones was not capable of improving adherence. Mobile health interventions are increasingly popular for implementing on a large scale in different chronic health conditions [51-53], but further research into these issues is needed. Despite the negative results that may be justified because of the study's limitations as described above, the study's results are not conclusive. However, an interesting fact that can be seen in both groups is that morning adherence to the inhaler is much higher than afternoon adherence. These data should be verified in a new well-designed clinical trial that could reinforce the use of ultralong action treatments, which only need to be taken once a day, in order to improve the adherence and control of asthma.

\section{Acknowledgments}

This project was funded by Sociedad Española de Neumología y Cirugía Torácica and Pfizer Spain.

\section{Authors' Contributions}

CM and ALV conceived the study. MA and AM verified the analytical methods. CA supervised the findings of this work. All authors discussed the results and contributed to the final manuscript.

\section{Conflicts of Interest}

None declared.

\section{References}

1. Rabe KF, Adachi M, Lai CKW, Soriano JB, Vermeire PA, Weiss KB, et al. Worldwide severity and control of asthma in children and adults: the global asthma insights and reality surveys. J Allergy Clin Immunol 2004 Jul;114(1):40-47. [doi: 10.1016/j.jaci.2004.04.042] [Medline: 15241342]

2. López-Viña A, Cimas J, Díaz Sánchez C, Coria G, Vegazo O, Picado Valles C, Scientific Committee of ASES study. A comparison of primary care physicians and pneumologists in the management of asthma in Spain: ASES study. Respir Med 2003 Aug;97(8):872-881 [FREE Full text] [doi: 10.1016/s0954-6111(03)00041-6] [Medline: 12924513 ] 
3. Fueyo A, Ruiz M, Ancochea J, Guilera M, Badia X, ESCASE Group. Asthma control in Spain. Do season and treatment pattern matter? The ESCASE study. Respir Med 2007 May;101(5):919-924 [FREE Full text] [doi: 10.1016/j.rmed.2006.09.017] [Medline: 17079125]

4. Horn C, Clark T, Cochrane G. Compliance with inhaled therapy and morbidity from asthma. Respir Med 1990 Jan;84(1):67-70. [doi: 10.1016/s0954-6111(08)80097-2] [Medline: 2371425]

5. Soriano JB, Rabe KF, Vermeire PA. Predictors of poor asthma control in European adults. J Asthma 2003;40(7):803-813. [doi: 10.1081/jas-120023572] [Medline: 14626337]

6. Pollard S, Bansback N, FitzGerld JM, Bryan S. The burden of nonadherence among adults with asthma: a role for shared decision-making. Allergy 2017 May;72(5):705-712. [doi: 10.1111/all.13090] [Medline: 27873330]

7. Corrao G, Arfè A, Nicotra F, Ghirardi A, Vaghi A, Pesci A, CRD Real-World Evidence Scientific Board. Persistence with inhaled corticosteroids reduces the risk of exacerbation among adults with asthma: a real-world investigation. Respirology 2016 Dec;21(6):1034-1040. [doi: 10.1111/resp.12791] [Medline: 27061430]

8. Ban G, Trinh THK, Ye Y, Park H. Predictors of asthma control in elderly patients. Curr Opin Allergy Clin Immunol 2016 Dec;16(3):237-243. [doi: 10.1097/ACI.0000000000000273] [Medline: 27054316]

9. Fischer J, Wimmer A, Mahlich J. [Medication adherence in asthma therapy-a structured review]. Pneumologie 2013 Jul;67(7):406-414 [FREE Full text] [doi: 10.1055/s-0033-1344242] [Medline: 23797492]

10. Normansell R, Kew KM, Stovold E. Interventions to improve adherence to inhaled steroids for asthma. Cochrane Database Syst Rev 2017 Apr 18;4:CD012226. [doi: 10.1002/14651858.CD012226.pub2] [Medline: 28417456]

11. Bender B, Milgrom H, Rand C. Nonadherence in asthmatic patients: is there a solution to the problem? Ann Allergy Asthma Immunol 1997 Sep;79(3):177-185. [doi: 10.1016/S1081-1206(10)63001-3] [Medline: 9305223]

12. Rand CS, Wise RA. Measuring adherence to asthma medication regimens. Am J Respir Crit Care Med 1994 Feb;149(2 Pt 2):S69-576. [doi: 10.1164/ajrccm/149.2_Pt_2.S69] [Medline: $\underline{\text { 8298770] }}$

13. Cerveri I, Locatelli F, Zoia MC, Corsico A, Accordini S, de Marco R. International variations in asthma treatment compliance: the results of the European Community Respiratory Health Survey (ECRHS). Eur Respir J 1999 Aug;14(2):288-294 [FREE Full text] [doi: 10.1034/j.1399-3003.1999.14b09.x] [Medline: 10515403]

14. Reid D, Abramson M, Raven J, Walters HE. Management and treatment perceptions among young adults with asthma in Melbourne: the Australian experience from the European Community Respiratory Health Survey. Respirology 2000 Sep;5(3):281-287. [doi: 10.1046/j.1440-1843.2000.00265.x] [Medline: 11022992]

15. Gamble J, Stevenson M, McClean E, Heaney LG. The prevalence of nonadherence in difficult asthma. Am J Respir Crit Care Med 2009 Nov 01;180(9):817-822. [doi: 10.1164/rccm.200902-0166OC] [Medline: 19644048]

16. Møldrup C, Stein J, Søndergaard B. "Patients don't lie"; a view on adherence in asthma. Pharm World Sci 2010 Dec;32(6):795-798. [doi: 10.1007/s11096-010-9439-0] [Medline: 20924676]

17. Foster JM, Smith L, Bosnic-Anticevich SZ, Usherwood T, Sawyer SM, Rand CS, et al. Identifying patient-specific beliefs and behaviours for conversations about adherence in asthma. Intern Med J 2012 Jun;42(6):e136-e144. [doi:

10.1111/j.1445-5994.2011.02541.x] [Medline: 21627747]

18. Cohen JL, Mann DM, Wisnivesky JP, Home R, Leventhal H, Musumeci-Szabó TJ, et al. Assessing the validity of self-reported medication adherence among inner-city asthmatic adults: the Medication Adherence Report Scale for Asthma. Ann Allergy Asthma Immunol 2009 Oct;103(4):325-331. [doi: 10.1016/s1081-1206(10)60532-7] [Medline: 19852197]

19. Plaza V. Update on questionnaires for assessing adherence to inhaler devices in respiratory patients. Curr Opin Allergy Clin Immunol 2018 Feb;18(1):44-50. [doi: 10.1097/ACI.0000000000000410] [Medline: 29135485]

20. Plaza V, López-Viña A, Entrenas LM, Fernández-Rodríguez C, Melero C, Pérez-Llano L, et al. Differences in adherence and non-adherence behaviour patterns to inhaler devices between COPD and asthma patients. COPD 2016 Dec;13(5):547-554. [doi: 10.3109/15412555.2015.1118449] [Medline: 26788620]

21. Plaza V, Fernández-Rodríguez C, Melero C, Cosío BG, Entrenas LM, Gutiérrez-Pereyra F, et al. Validation of the 'Test of the Adherence to Inhalers' (TAI) for asthma and COPD patients. J Aerosol Med Pulm Drug Deliv 2016 Apr;29(2):142-152 [FREE Full text] [doi: 10.1089/jamp.2015.1212] [Medline: 26230150]

22. Gilbert JR, Evans CE, Haynes RB, Tugwell P. Predicting compliance with a regimen of digoxin therapy in family practice. Can Med Assoc J 1980 Jul 19;123(2):119-122 [FREE Full text] [Medline: 7260749]

23. Rand CS, Wise RA, Nides M, Simmons MS, Bleecker ER, Kusek JW, et al. Metered-dose inhaler adherence in a clinical trial. Am Rev Respir Dis 1992 Dec;146(6):1559-1564. [doi: 10.1164/ajrccm/146.6.1559] [Medline: 1456575]

24. Katsara M, Donnelly D, Iqbal S, Elliott T, Everard ML. Relationship between exhaled nitric oxide levels and compliance with inhaled corticosteroids in asthmatic children. Respir Med 2006 Sep;100(9):1512-1517 [FREE Full text] [doi: 10.1016/j.rmed.2006.01.012] [Medline: 16504494]

25. Wamboldt FS, Bender BG, O'Connor SL, Gavin LA, Wamboldt MZ, Milgrom H, et al. Reliability of the model MC-311 MDI chronolog. J Allergy Clin Immunol 1999 Jul;104(1):53-57. [doi: 10.1016/s0091-6749(99)70113-2] [Medline: 10400839]

26. Simmons MS, Nides MA, Rand CS, Wise RA, Tashkin DP. Unpredictability of deception in compliance with physician-prescribed bronchodilator inhaler use in a clinical trial. Chest 2000 Aug;118(2):290-295. [doi: 10.1378/chest.118.2.290] [Medline: 10936115] 
27. Bosley CM, Parry DT, Cochrane GM. Patient compliance with inhaled medication: does combining beta-agonists with corticosteroids improve compliance? Eur Respir J 1994 Mar;7(3):504-509 [FREE Full text] [doi: 10.1183/09031936.94.07030504] [Medline: 8013609]

28. Bogen D, Apter AJ. Adherence logger for a dry powder inhaler: a new device for medical adherence research. J Allergy Clin Immunol 2004 Oct;114(4):863-868. [doi: 10.1016/j.jaci.2004.07.017] [Medline: 15480328]

29. Cleland J, Caldow J, Ryan D. A qualitative study of the attitudes of patients and staff to the use of mobile phone technology for recording and gathering asthma data. J Telemed Telecare 2007;13(2):85-89. [doi: 10.1258/135763307780096230] [Medline: 17359572]

30. Ostojic V, Cvoriscec B, Ostojic SB, Reznikoff D, Stipic-Markovic A, Tudjman Z. Improving asthma control through telemedicine: a study of short-message service. Telemed J E Health 2005 Feb;11(1):28-35. [doi: 10.1089/tmj.2005.11.28] [Medline: $\underline{15785218]}$

31. Ryan D, Cobern W, Wheeler J, Price D, Tarassenko L. Mobile phone technology in the management of asthma. J Telemed Telecare 2005;11 Suppl 1:43-46. [doi: 10.1258/1357633054461714] [Medline: 16035991]

32. Fonseca JA, Costa-Pereira A, Delgado L, Fernandes L, Castel-Branco MG. Asthma patients are willing to use mobile and web technologies to support self-management. Allergy 2006 Mar;61(3):389-390. [doi: 10.1111/j.1398-9995.2006.01016.x] [Medline: 16436151]

33. Morrison D, Mair FS, Chaudhuri R, McGee-Lennon M, Thomas M, Thomson NC, et al. Details of development of the resource for adults with asthma in the RAISIN (randomized trial of an asthma internet self-management intervention) study. BMC Med Inform Decis Mak 2015 Jul 28;15:57 [FREE Full text] [doi: 10.1186/s12911-015-0177-z] [Medline: 26215651]

34. Pool AC, Kraschnewski JL, Poger JM, Smyth J, Stuckey HL, Craig TJ, et al. Impact of online patient reminders to improve asthma care: a randomized controlled trial. PLoS One 2017;12(2):e0170447 [FREE Full text] [doi:

10.1371/journal.pone.0170447] [Medline: 28158200]

35. Foster JM, Usherwood T, Smith L, Sawyer SM, Xuan W, Rand CS, et al. Inhaler reminders improve adherence with controller treatment in primary care patients with asthma. J Allergy Clin Immunol 2014 Dec;134(6):1260-1268. [doi: 10.1016/j.jaci.2014.05.041] [Medline: 25062783]

36. Geryk LL, Roberts CA, Sage AJ, Coyne-Beasley T, Sleath BL, Carpenter DM. Parent and clinician preferences for an asthma app to promote adolescent self-management: a formative study. JMIR Res Protoc 2016 Dec 06;5(4):e229 [FREE Full text] [doi: 10.2196/resprot.5932] [Medline: 27923777]

37. Foster JM, Reddel HK, Usherwood T, Sawyer SM, Smith L. Patient-perceived acceptability and behaviour change benefits of inhaler reminders and adherence feedback: a qualitative study. Respir Med 2017 Dec;129:39-45. [doi: 10.1016/j.rmed.2017.05.013] [Medline: 28732834]

38. Foster JM, Smith L, Usherwood T, Sawyer SM, Rand CS, Reddel HK. The reliability and patient acceptability of the SmartTrack device: a new electronic monitor and reminder device for metered dose inhalers. J Asthma 2012 Aug;49(6):657-662. [doi: 10.3109/02770903.2012.684253] [Medline: 22741746]

39. Cushing A, Manice MP, Ting A, Parides MK. Feasibility of a novel mHealth management system to capture and improve medication adherence among adolescents with asthma. Patient Prefer Adherence 2016;10:2271-2275 [FREE Full text] [doi: 10.2147/PPA.S115713] [Medline: 27853357]

40. Chan AHY, Reddel HK, Apter A, Eakin M, Riekert K, Foster JM. Adherence monitoring and e-health: how clinicians and researchers can use technology to promote inhaler adherence for asthma. J Allergy Clin Immunol Pract 2013;1(5):446-454. [doi: 10.1016/j.jaip.2013.06.015] [Medline: 24565615]

41. 2017 GINA report: global strategy for asthma management and prevention. Global Initiative for Asthma. URL: https:/ /ginasthma.org/wp-content/uploads/2019/04/wmsGINA-2017-main-report-final V2.pdf [accessed 2017-09-02]

42. Vega JM, Badia X, Badiola C, López-Viña A, Olaguíbel JM, Picado C, Covalair Investigator Group. Validation of the Spanish version of the Asthma Control Test (ACT). J Asthma 2007 Dec;44(10):867-872. [doi: 10.1080/02770900701752615] [Medline: 18097865]

43. Miller MR, Hankinson J, Brusasco V, Burgos F, Casaburi R, Coates A, et al. Standardisation of spirometry. Eur Respir J 2005 Aug;26(2):319-338 [FREE Full text] [doi: 10.1183/09031936.05.00034805] [Medline: 16055882]

44. Roca J, Sanchis J, Agusti-Vidal A, Segarra F, Navajas D, Rodriguez-Roisin R, et al. Spirometric reference values from a Mediterranean population. Bull Eur Physiopathol Respir 1986;22(3):217-224. [Medline: 3730638]

45. Dweik RA, Boggs PB, Erzurum SC, Irvin CG, Leigh MW, Lundberg JO, American Thoracic Society Committee on Interpretation of Exhaled Nitric Oxide Levels (FENO) for Clinical Applications. An official ATS clinical practice guideline: interpretation of exhaled nitric oxide levels (FENO) for clinical applications. Am J Respir Crit Care Med 2011 Sep 01;184(5):602-615 [FREE Full text] [doi: 10.1164/rccm.9120-11ST] [Medline: 21885636]

46. Strandbygaard U, Thomsen SF, Backer V. A daily SMS reminder increases adherence to asthma treatment: a three-month follow-up study. Respir Med 2010 Feb;104(2):166-171 [FREE Full text] [doi: 10.1016/j.rmed.2009.10.003] [Medline: 19854632]

47. Charles T, Quinn D, Weatherall M, Aldington S, Beasley R, Holt S. An audiovisual reminder function improves adherence with inhaled corticosteroid therapy in asthma. J Allergy Clin Immunol 2007 Apr;119(4):811-816. [doi: 10.1016/j.jaci.2006.11.700] [Medline: 17320942] 
48. Patel M, Pilcher J, Chan A, Perrin K, Black P, Beasley R. Six-month in vitro validation of a metered-dose inhaler electronic monitoring device: implications for asthma clinical trial use. J Allergy Clin Immunol 2012 Dec;130(6):1420-1422. [doi: 10.1016/j.jaci.2012.06.037] [Medline: 22920492]

49. Patel M, Pilcher J, Travers J, Perrin K, Shaw D, Black P, et al. Use of metered-dose inhaler electronic monitoring in a real-world asthma randomized controlled trial. J Allergy Clin Immunol Pract 2013 Jan;1(1):83-91. [doi:

10.1016/j.jaip.2012.08.004] [Medline: 24229826]

50. Cisneros C, Díaz-Campos RM, Marina N, Melero C, Padilla A, Pascual S, et al. Accreditation of specialized asthma units for adults in Spain: an applicable experience for the management of difficult-to-control asthma. J Asthma Allergy 2017;10:163-169 [FREE Full text] [doi: 10.2147/JAA.S131506] [Medline: 28533690]

51. Vervloet M, van Dijk L, de Bakker DH, Souverein PC, Santen-Reestman J, van Vlijmen B, et al. Short- and long-term effects of real-time medication monitoring with short message service (SMS) reminders for missed doses on the refill adherence of people with type 2 diabetes: evidence from a randomized controlled trial. Diabet Med 2014 Jul;31(7):821-828. [doi: 10.1111/dme.12439] [Medline: 24646343]

52. Marcolino MS, Oliveira JAQ, D'Agostino M, Ribeiro AL, Alkmim MBM, Novillo-Ortiz D. The impact of mHealth interventions: systematic review of systematic reviews. JMIR Mhealth Uhealth 2018 Jan 17;6(1):e23 [FREE Full text] [doi: 10.2196/mhealth.8873] [Medline: 29343463]

53. Gregoriano C, Dieterle T, Dürr S, Arnet I, Hersberger KE, Leuppi JD. Impact of an electronic monitoring intervention to improve adherence to inhaled medication in patients with asthma and chronic obstructive pulmonary disease: study protocol for a randomized controlled trial. JMIR Res Protoc 2017 Oct 23;6(10):e204 [FREE Full text] [doi: 10.2196/resprot.7522] [Medline: 29061556]

\author{
Abbreviations \\ ACT: Asthma Control Test \\ ERS/ATS: European Respiratory Society/American Thoracic Society \\ FeNO: exhaled nitric oxide \\ FEV1: forced expiratory volume in 1 second \\ GINA: Global Initiative for Asthma \\ ICS/LABA: inhaled combination of corticosteroids and a long-acting beta 2 agonist \\ SMS: short message service
}

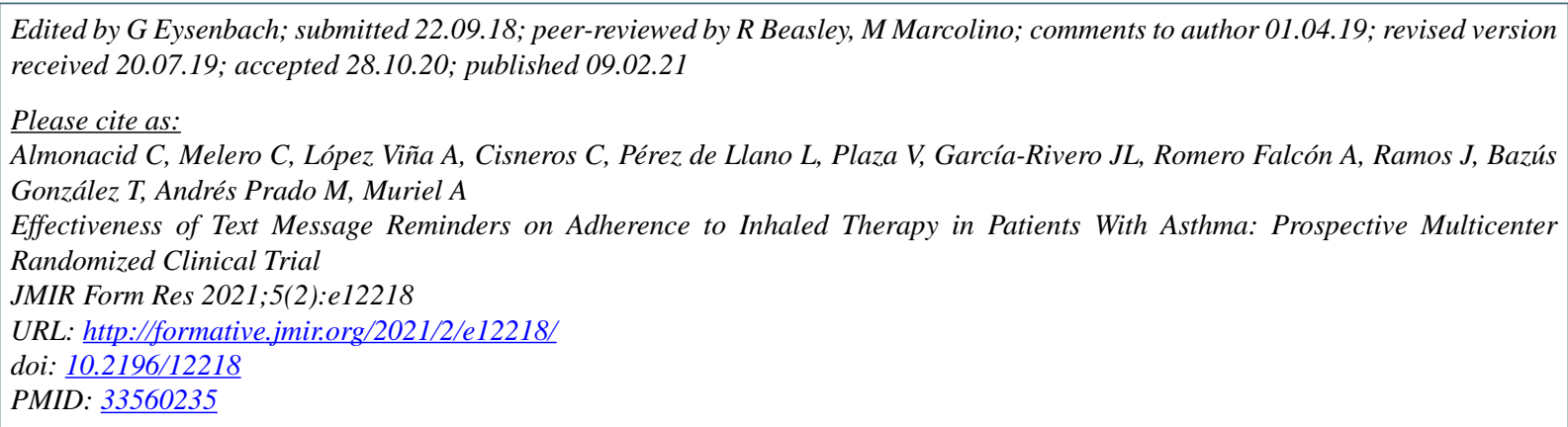

(C) Carlos Almonacid, Carlos Melero, Antolín López Viña, Carolina Cisneros, Luis Pérez de Llano, Vicente Plaza, Juan Luis García-Rivero, Auxiliadora Romero Falcón, Jacinto Ramos, Teresa Bazús González, María Andrés Prado, Alfonso Muriel. Originally published in JMIR Formative Research (http://formative.jmir.org), 09.02.2021. This is an open-access article distributed under the terms of the Creative Commons Attribution License (https://creativecommons.org/licenses/by/4.0/), which permits unrestricted use, distribution, and reproduction in any medium, provided the original work, first published in JMIR Formative Research, is properly cited. The complete bibliographic information, a link to the original publication on http://formative.jmir.org, as well as this copyright and license information must be included. 